\title{
CFU bacterial fraction in the estuarine upwelling ecosystem of Ría de Vigo, Spain: variability in abundance and their ecophysiological description
}

\author{
M. K. Zdanowski ${ }^{1}$, F. G. Figueiras ${ }^{2, *}$ \\ ${ }^{1}$ Department of Antarctic Biology, Polish Academy of Sciences, 02-141 Warsaw, Ustrzycka 10, Poland \\ ${ }^{2}$ Instituto de Investigacións Marinas, CSIC, Eduardo Cabello 6, E-36208 Vigo, Spain
}

\begin{abstract}
Between October 1990 and August 1991 colony-forming unit (CFU) bacteria at the centre of the Ría de Vigo, Spain, comprised on average $1 \%$ of total bacterioplankton, with a maximum of $6.8 \%$ in mid-April. In contrast to relatively small fluctuations in total bacterioplankton, fluctuations in CFUs were considerable, with the coefficient of variation ranging from 112 to $233 \%$. Over $40 \%$ of the variance in CFU abundance in the surface layer during the whole period of observations (winter and summer) could be explained through an equation relating logCFU to incoming solar radiation, and during the summer months through another equation relating logCFU to upwelling. Both physical factors enhanced CFU concentrations. Biological variables, such as total bacterioplankton, chlorophyll and heterotrophic flagellates, had no further effect on the explained variance. At the bottom of the photic zone, runoff and upwelling accounted for between 29 and $50 \%$ of the variance in CFU counts. In this layer, biological variables had a great influence on CFU abundance, increasing the explained variance to $61 \%$ for the whole period studied. In this case, chlorophyll was negatively related to logCFU suggesting that the CFU bacterial fraction was more abundant in the water column after the decline of the phytoplankton blooms and after the corresponding release of bacteria attached to particles. At the bottom of the water column, seawater temperature was the only important factor in explaining the variance in CFU counts (36\%), with logCFU and temperature being positively related. We hypothesise that 3 factors are prominent in controlling the CFU standing stock: solar radiation and upwelling stimulate the synthesis of particulate organic matter in surface waters, providing a food source for CFU bacteria, and terrestrial runoff which dilutes bacterial numbers. Based on cluster analyses of physiological tests, on pure bacterial isolates from 2 contrasting sampling dates, we show that prevailing hydro- and meteorological conditions select for different bacterial species in the CFU community. Lower CFU counts and diversity within the population, plus lower frequencies of positive responses in physiological tests arose through very high upwelling and NW winds which introduced CFU-poor water masses from the Atlantic Ocean into the Ría de Vigo. Conversely, terrestrial runoff and NE winds enhanced diversity within this population at the centre of the estuary, through the introduction of terrestrial bacteria or those from shallow waters; these were characterised by higher numbers of positive responses in physiological tests.
\end{abstract}

KEY WORDS: CFU bacterial fraction - Hydrographic variability Upwelling $\cdot$ Runoff $\cdot$ Ecophysiology Estuarine ecosystem - Ría de Vigo

\section{INTRODUCTION}

The waters of the Ría de Vigo (Galicia, Spain) have been studied extensively since the 1950s. Changes in

\footnotetext{
-Addressee for correspondence.
}

E-mail: paco@iim.csic.es the estuary's hydrology driven by incoming solar radiation, fluvial discharge, and coastal upwelling have been well described (Fraga 1967, Fraga \& Margalef 1979, Ríos et al. 1992, Alvarez-Salgado et al. 1993, Doval et al. 1997). A large body of work describes the high primary productivity rates and factors controlling phytoplankton growth in this area (e.g. Figueiras et al. 1994, Mon- 
coiffe 1995, Fermin et al. 1996), but few data exist on bacteria in the Galician Rías ecosystem. As an initial step in our studies of bacteria in the Ría de Vigo (Zdanowski \& Figueiras 1997) we have described interactions between the total bacterioplankton and other biotic and abiotic parameters. We also show that the total bacterial abundance was strongly affected by physical factors in the Ría. In this paper we describe factors that affect the colony-forming unit (CFU) bacteria, those which might be considered trophically dependent on particulate organic matter (POM). Colonising and converting particles to dissolved organic matter (DOM) (Soutar et al. 1977, Karl \& Knauer 1984), these CFU bacteria, which constitute a small fraction of the total bacteria (Mann 1973, Kirchman 1993), may play an important role in the flux of POM into bacterioplankton, and thence to higher trophic levels (Zdanowski \& Figueiras 1997). By degrading complex biotic and abiotic molecules, they can also serve as donors of digestive enzymes in animal nutrition (Harris 1993, Donachie et al. 1995), or remove complex molecules from the natural environment (Zdanowski 1977, 1979), and may play an important role in the elimination of municipal or industrial pollutants. This work was considered to be an introduction to prospective studies on ecological interactions between marine bacteria and particles of biotic and abiotic origin with an emphasis on food web dynamics in Ría de Vigo. It was performed using quantitative and qualitative methods to characterise the bacterioplankton fraction which could be trophically dependent on POM, but which occurs transiently in the free state. In an environmental situation with a wide range of poorly described genera of marine bacteria, conventional taxonomic methods for identifying bacteria are impractical. Instead, commercially available diagnostic systems such as those produced by API bioMerieux have been applied (Bouvy \& Delille 1987, Tearle \& Richard 1987. Zdanowski \& Donachie 1993). Then, combined with other data on cell and colony morphology, we compared diversity within the CFU populations at 3 depths of the water column and under different environmental conditions in the Ría de Vigo. The similarities among pure bacterial cultures were the basis for grouping them using numerical taxonomy. Furthermore, we attempted to identify these pure cultures on the basis of their responses to the tests described above and through comparison with type culture species.

\section{MATERIAL AND METHODS}

Sampling was done once a week between 31 October 1990 and 19 August 1991 at Stn 3b in the Ría de Vigo (Fig. 1). This station has been used for regular

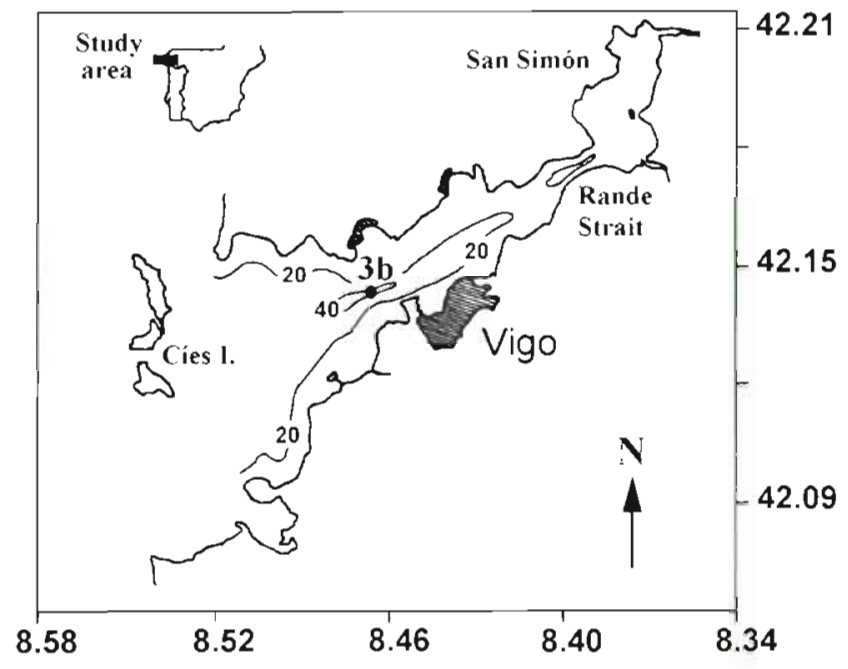

Fig. 1. Location of the Ría de Vigo (northwest corner of Iberian peninsula) showing the sampling station ( $3 \mathrm{~b}$ ) during this work. The isobaths of 20 and $40 \mathrm{~m}$ are indicated

oceanographic sampling since 1987 (Zdanowski \& Figueiras 1997). Samples were collected from the surface $(0 \mathrm{~m})$, from the middle layer (characterised by $1 \%$ of the irradiance at the seasurface), and from the bottom layer ( $\sim 5 \mathrm{~m}$ above the bottom).

Seawater temperature $\left({ }^{\circ} \mathrm{C}\right)$ and density $\left(\sigma_{t}\right)$ were determined by CTD. The upwelling index for the previous $3 \mathrm{~d}$ plus the sampling day (Upw4) was calculated using geostrophic winds off Cape Finisterre derived from surface pressure charts 3 times $d^{-1}$ (Bakun 1973). Runoff (Qr4) was calculated following the equation proposed by Ríos et al. (1992), taking into account the rainfall of the 3 preceding days and using a retention coefficient of 0.75 . Mean incoming solar radiation during the 3 preceding days plus the sampling day (Qs4) was estimated by Mosby's formula (Dietrich et al. 1980). Chlorophyll a (chl a) was determined by fluorometry (Yentsch \& Menzel 1963).

Total heterotrophic bacterioplankton (DAPI-TC) were enumerated in water fixed with buffered formalin (4\% final conc.) by epifluorescence microscopy on $0.2 \mu \mathrm{m}$ black Millipore polycarbonate filters, using DAPI (4',6-diamidino-2-phenylindole) (Porter \& Feig 1980). Cyanobacteria (Cyan) were counted in parallel to these preparations after Davis \& Sieburth (1982); both total and dividing cyanobacteria cells were counted. The abundance of heterotrophic picoflagellates $(\mathrm{HPF})(\leq 2 \mu \mathrm{m})$ and heterotrophic nanoflagellates (HNF) (between 2 and $20 \mu \mathrm{m}$ ) was determined in the same samples in which total bacteria and cyanobacteria were counted. Ciliates (Cil) were counted in samples fixed with Lugol's iodine using an inverted microscope. 
Water samples for enumeration and description of CFU were taken with an ethanol rinsed 5 l plastic Van Dorn bottle (Kriss et al. 1969). The first fraction of the water in the sampler was discarded by flushing through the tap. Thereafter, subsamples $(-100 \mathrm{ml})$ were immediately transferred to sterile, opaque, screw-capped glass bottles and maintained at $-5^{\circ} \mathrm{C}$ until processed in the laboratory (2 to $3 \mathrm{~h}$ ). CFU were described using Difco media. Total CFU were isolated on Bacto Marine Agar 2216 (MA) (ZoBell 1941), which was prepared either as standard MA (undiluted - MA $100 \%$ ) or $10 \times$ diluted (MA 10\%). For Pseudomonas species we used Bacto Pseudomonas Selective Agar (PSA) (King et al. 1954). Vibrio species were isolated on bacto thiosulphate citrate bile sucrose agar (TCBS) (West et al. 1982). All media were prepared using 'aged' seawater Agar plates (4 replicates medium-1) were inoculated with $0.1 \mathrm{ml}$ of undiluted (MA, PSA, TCBS) or diluted sample (MA, diluted with sterile, $0.2 \mu \mathrm{m}$ filtered and autoclaved seawater). For the purpose of CFU counts, agar plates were inoculated with $0.1 \mathrm{ml}$ diluted seawater. Such procedure limited the presence of particle-bound bacteria in inoculates, which was confirmed by direct microscopy and therefore the counted CFU bacteria might be considered as in free-stage. Plates were incubated in darkness for up to $15 \mathrm{~d}$ at $24^{\circ} \mathrm{C}$. The effect of undiluted or $10 \times$ diluted ZoBell's medium on CFU counts was checked in 23 samples throughout the sampling period and for the 3 sampled layers. There were no significant differences in CFU counts (t-tests, ns), suggesting that neither diluted nor undiluted medium is superior for isolating CFU.

Spore-forming aerobic bacteria (CFUs) were described in terms of CFU through heat-resistant spores: $10 \mathrm{ml}$ of water was incubated at $80^{\circ} \mathrm{C}$ for $10 \mathrm{~min}$, then mixed with $10 \mathrm{ml}$ of double-strength Bacto Marine Agar 2216 (ZoBell 1941) and dispensed into Petri dishes (Fenchel \& Hemmingsen 1974).

Ecophysiological and morphological descriptions of CFU were based on the results provided by the API 20NE system (bioMereiux 1990a) and on macroscopic observations of colonies, microscopic observations of bacteria (including Gram reaction), cell morphology, and motility. API 20NE is designed, in principle, to identify non-enteric Gram-negative rods (Geiss et al. 1985, Tearle \& Richard 1987, Zdanowski 1995), and provides information describing the response of bacterial isolates to 8 conventional tests (biochemical), 12 assimilation tests and the cytochrome oxidase test. To provide further information on CFU characteristics, the RAPID 20E test (bioMerieux 1990b) for identification of Enterobacteriaceae was applied to 10 oxidase negative, Gram-negative rod cultures isolated on MA, and to 15 cultures isolated on TCBS. To provide infor- mation on bacterial constitutive enzyme activities, the semi-quantitative micro-method API Zym was employed. Only those colonies that produced suspensions of the required turbidity (McFarland Nos. 5 to 6) (Washington et al. 1972) were tested.

All procedures were conducted in accordance with the manufacturer's instructions, with some modifications to take culture histories into account. Subcultured bacteria growing on solid media were suspended in the 3 bioMerieux media modified by the addition of $\mathrm{NaCl}$ to $3.4 \%$. The recommended incubation temperatures of $30^{\circ} \mathrm{C}$ (API 20NE, RAPID 20E) for $24 \mathrm{~h}$, and $37^{\circ} \mathrm{C}$ (Zym) for $4 \mathrm{~h}$ were considered too high and too short for temperate marine bacteria. Incubations for API $20 \mathrm{NE}$ and RAPID $20 \mathrm{E}$ systems were done at $24^{\circ} \mathrm{C}$ for $48 \mathrm{~h}$. API Zym systems were incubated at $24^{\circ} \mathrm{C}$ for $8 \mathrm{~h}$, after which time the required API reagents were added as directed.

On the basis of 2 experiments (Expt 7 [10 December] and Expt 13 [14 February]), differences between bacterial populations under different environmental conditions, and between populations in surface, middle and bottom layers, are described. Responses of bacterial isolates from each experiment $(67$ isolates from Expt 7 and 115 isolates from Expt 13) were compared in terms of the frequency of positive responses in the API $20 \mathrm{NE}$ system and their morphological description. These results were statistically analysed using chisquared tests. Isolates tested in API 20NE displayed a wide range of responses, from mostly negative, to mostly positive. Responses were converted into numerical profiles (i.e. a number that describes the responses shown in the system by each bacterial culture), thus permitting comparison with those of type species in the Analytical Profile Index (bioMereiux 1990a, b). Identification through API systems is based on comparing the observed profile to the different taxa in the database (\% i.d.) and determinig its proximity to the most typical profile in each of the taxa ( $\mathrm{T}$ index). A cluster analysis was applied to compare isolates from Expts 7 and 13. Two dendrograms showing the hierarchical classification of isolates in the 2 experiments were constructed by the simple matching coefficient of Sokal \& Michener (1958) in association with the weight-pair-groupmedian algorithm (Sneath \& Sokal 1974).

\section{RESULTS}

\section{CFU abundance}

The study period was divided into winter (November to February) and summer (March to August) periods on the basis of incoming solar radiation (Qs4) according to Zdanowski \& Figueiras (1997). Throughout the study, CFUs in the Ría de Vigo numbered from 85 
(August, bottom layer) to $250 \times 10^{3} \mathrm{~m}^{-1}$ (April, surface layer). Considerable fluctuations in CFUs occurred between sampling days at each depth (Fig. 2). On average, CFUs constituted $\sim 1 \%$ of the total bacteria (DAPI-TC). The largest CFU:DAPI-TC fraction $(6.8 \%)$ occurred on 15 April, when both maximal CFU and DAPI-TC counts coincided with maximal upwelling (Table 1). In general, the pattern of seasonal changes in CFU differed to that shown by DAPI-TC. Only at the surface did we record an increase in CFU with the winter to summer transition (Fig. 2), while this transition was reflected in DAPI-TC increases at each depth (Table 1, see also Zdanowski \& Figueiras 1997). On average, CFU numbers in summer were 3.8 times greater than in winter in the surface layer.

The size of the CFU fraction tended to decrease with depth (Fig. 2, Table 1). The most notable exception, however, was observed in winter (Expt 7 [10 December] and Expt 8 [20 December]) when CFU counts were considerably more uniform over the water column compared to their mean values for the entire winter period (Fig. 2, Table 1). Relatively uniform DAPI-TC numbers throughout the water column were also found on these dates. Upw4 was high and Qr4 relatively low at this time when temperature was lowest and density highest at the surface. This contrasted with the usual winter situation for these parameters (Table 1). During Expt 13 (14 February) the water column showed typically winter values for temperature, density, CFU, and DAPI-TC. Runoff was not separated from the mean winter values

With the aid of multiple stepwise regression we tried to determine what might account for changes in CFU numbers in the Ría de Vigo during this study. Tables 2 , $3 \& 4$ show the output of these analyses. The first thing that appears evident is the little importance of biological variables in explaining the variability in CFU counts in surface and bottom layers (Tables $2 \& 4$ ). Conversely, the explained variability in CFU abundance was higher when biological variables were included in the regressions for the middle layer (Table 3), especially during the whole study period (winter and summer).

Forty-two percent of the variance in CFU bacterial abundance in the surface (Table 2) throughout the study (winter and summer) could be explained by a positive relationship with Qs4, and less so by a negative relationship with temperature. During summer alone, almost $45 \%$ of the variance could be explained through upwelling. The inclusion of biological variables in the regression equation did not change the pattern in summer. However, the inclusion of biological variables caused an increase in the explained vari-
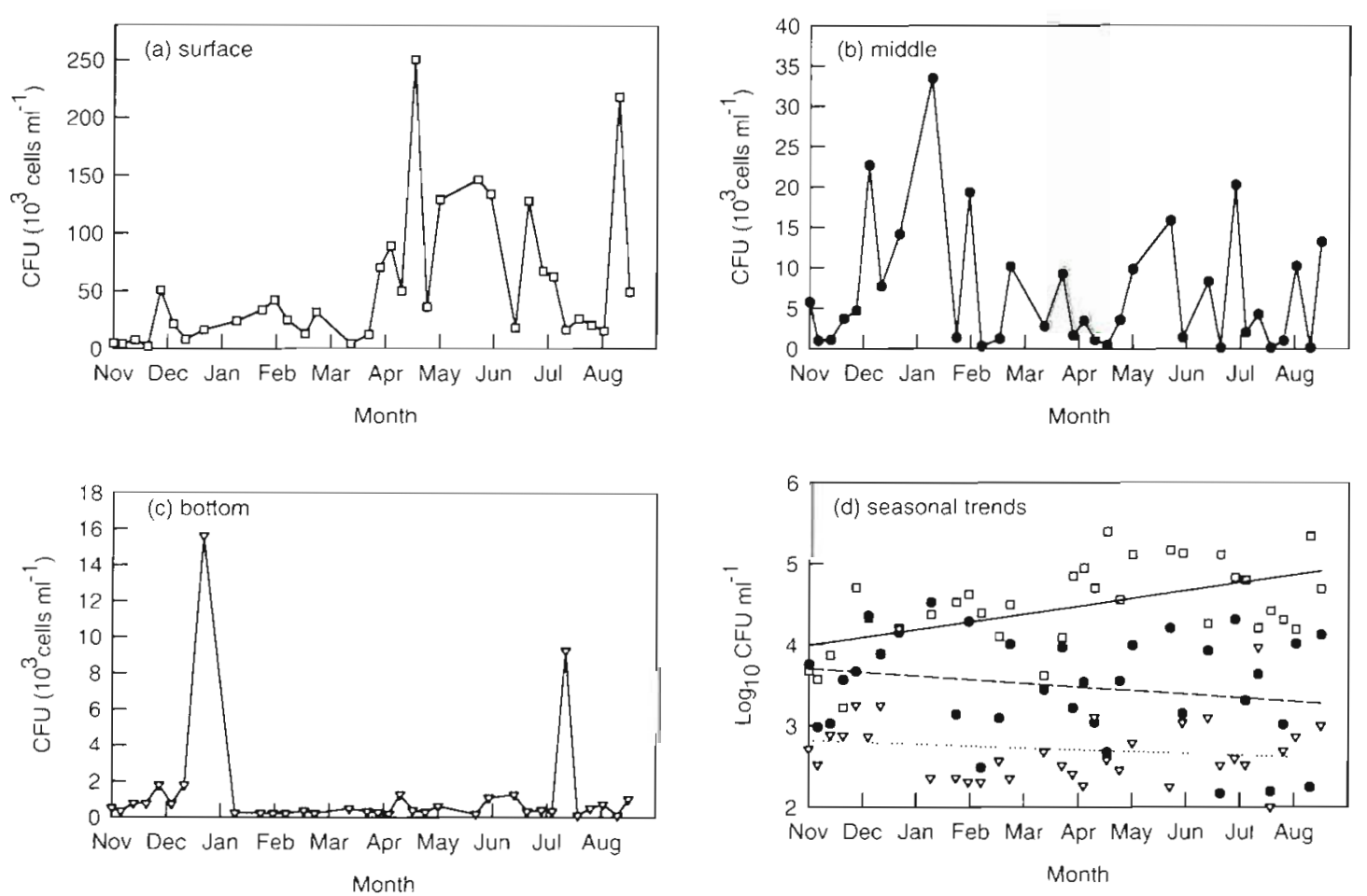

Fig. 2. Total numbers of colony-forming unit (CFU) bacteria in the (a) surface, (b) middle (bottom of the photic layer) and (c) bottom waters at Stn $3 b$ in the Ría de Vigo, and (d) their seasonal trends, described by the following regression equations, $\cdots p<0.001$. surface $\left(a_{1} \longrightarrow\right), \log \mathrm{CFU}=3.995+0.003 \cdots$ Julian Day, $r^{2}=0.30 \cdots, \mathrm{n}=34$; middle $(\bullet,---), \log \mathrm{CFU}=3.704-0.001 \mathrm{Julian}$ Day, $r^{2}=0.04, n=34$; bottom $(\nabla, \cdots \cdots), \log C F U=2.819-0.001$ Jullan Day, $r^{2}=0.02, n=34$ 
Table 1. Colony-forming units (CFU) and total (DAPI-TC) bacterial numbers, density $\left(\sigma_{1}\right)$, temperature $\left({ }^{\circ} \mathrm{C}\right)$, runoff $(\mathrm{Q} r 4)$, upwelling (Upw4), and solar radiation (Qs4) at 3 depths (S: surface, M: middle, B: bottom) in the Ría de Vigo (Stn 3b), during 4 experiments ( 3 winter and 1 summer). For comparison, average values for the whole winter and summer periodsare presented

\begin{tabular}{|c|c|c|c|c|c|c|c|c|}
\hline $\begin{array}{l}\text { Expt } \\
\text { no./date }\end{array}$ & Depth & $\begin{array}{c}\mathrm{CFU} \\
\times 10^{3} \mathrm{ml}^{-1}\end{array}$ & $\begin{array}{l}\text { DAPI-TC } \\
\times 10^{6} \mathrm{ml}^{-1}\end{array}$ & ${ }^{\circ} \mathrm{C}$ & $\sigma_{\mathrm{t}}$ & $\begin{array}{l}\text { Qr4: } \\
\mathrm{m}^{3} \mathrm{~s}^{-1}\end{array}$ & $\begin{array}{c}\text { Upw4: } \\
\mathrm{m}^{3} \mathrm{~s}^{-1} \mathrm{~km}^{-1}\end{array}$ & $\begin{array}{c}\text { Qs4: } \\
\text { cal } \mathrm{cm}^{-2} \mathrm{~d}^{-1}\end{array}$ \\
\hline \multirow{3}{*}{$7 / 10 \mathrm{Dec}$} & $\mathrm{S}$ & 7.66 & 1.11 & 10.49 & 26.99 & 8 & 1510 & 225 \\
\hline & $M$ & 7.68 & 1.09 & 13.14 & 26.51 & & & \\
\hline & $\mathrm{B}$ & 1.77 & 0.94 & 13.74 & 26.58 & & & \\
\hline \multirow[t]{3}{*}{$8 / 20 \mathrm{Dec}$} & $\mathrm{S}$ & 16.05 & 0.87 & 10.68 & 27.21 & 5 & 590 & 222 \\
\hline & $\mathrm{M}$ & 14.12 & 0.97 & 12.60 & 26.89 & & & \\
\hline & B & 15.60 & 0.85 & 12.61 & 26.91 & & & \\
\hline \multirow[t]{3}{*}{ 13/14 Feb } & $\mathrm{S}$ & 12.67 & 1.32 & 12.02 & 25.66 & 34 & 514 & 294 \\
\hline & M & 1.25 & 1.06 & 13.09 & 26.88 & & & \\
\hline & B & 0.37 & 0.98 & 13.28 & 26.92 & & & \\
\hline Winter & $\mathrm{S}$ & 20.06 & 1.27 & 13.11 & 24.85 & 33 & -141 & 251 \\
\hline \multirow[t]{2}{*}{ (average) } & M & 9.30 & 1.04 & 13.74 & 26.19 & & & \\
\hline & B & 1.69 & 0.86 & 13.90 & 26.62 & & & \\
\hline \multirow[t]{3}{*}{$20 / 15 \mathrm{Apr}$} & $\mathrm{S}$ & 250.37 & 3.67 & 13.30 & 25.87 & 11 & 1586 & 453 \\
\hline & $\mathrm{M}$ & 0.47 & 1.16 & 12.91 & 26.93 & & & \\
\hline & B & 0.38 & 1.28 & 12.71 & 27.02 & & & \\
\hline \multirow{3}{*}{$\begin{array}{l}\text { Summer } \\
\text { (average) }\end{array}$} & $\mathrm{S}$ & 77.05 & 2.57 & 14.95 & 25.64 & 6 & 282 & 546 \\
\hline & M & 5.48 & 1.40 & 13.17 & 26.54 & & & \\
\hline & $B$ & 0.95 & 1.28 & 12.65 & 26.94 & & & \\
\hline
\end{tabular}

ance (up to $58 \%$ ) in the CFU counts over the whole period. DAPI-TC and $\sigma_{\text {: }}$ were positively related with logCFU while numbers of Cyan and logCFU were negatively related.

Qr4, Upw4 and Qs4 explained 29 and $43 \%$ of CFU variance in the middle layer during the whole sampling period (winter and summer) and during summer, respectively (Table 3 ). The 3 physical variables were negatively related to CFU bacteria. In contrast, $61 \%$ of the variance in bacterial numbers during the whole sampling period and $55 \%$ during summer could be explained in part through biological variables such as DAPI-TC and chlorophyll concentration. DAPI-TC was always positively related to $\log \mathrm{CFU}$, whereas chlorophyll was negatively related.

Biological variables had no influence on CFU variability in the bottom layer (Table 4). The most striking feature in this layer was the positive relationship between temperature and CFU abundance during summer
Table 2. Multiple stepwise regression between logCFU and (A) physical and (B) physical and biological variables in the surface waters of the Ría de Vigo (Stn $3 b$ ). Results are presented for data collected during the full period of this study (Winter $[W]$ and Summer $[S], n=34$ ) and separately for $W(n=14)$ and $S$ $(n=20)$. ( $\beta$ ) Standardised coefficient of regression and $(p)$ level of significance of the slopes in the regression equations. Physical variables: ${ }^{\circ} \mathrm{C}$ (seawater temperature), $\sigma_{t}$ (seawater density), Qs4 (solar radiation) and Upw4 (upwelling index). Biological variables: TC (total bacterial counts), Cyan (cyanobacteria) and HPF (heterotrophic picoflagellates)

\begin{tabular}{|c|c|c|c|c|c|c|}
\hline \multirow[t]{2}{*}{ Variable } & \multicolumn{2}{|c|}{$W$ and $S$} & \multicolumn{2}{|c|}{ W } & \multicolumn{2}{|c|}{$\mathrm{S}$} \\
\hline & $\beta$ & $\mathrm{p}$ & $\beta$ & $\mathrm{p}$ & $\beta$ & $\mathrm{p}$ \\
\hline \multicolumn{7}{|l|}{ (A) } \\
\hline Qs4 & 0.834 & 0.000 & & & & \\
\hline${ }^{\circ} \mathrm{C}$ & -0.427 & 0.024 & -0.527 & 0.052 & & \\
\hline Upw4 & & & & & 0.665 & 0.001 \\
\hline \multicolumn{7}{|c|}{ Regression equations: } \\
\hline $\mathrm{W}$ and $\mathrm{S}$ & $\log C F U=$ & $.93+2$ & $0^{-3} \mathrm{Qs4}-$ & $0^{\circ} \mathrm{C} \quad r^{2}$ & & \\
\hline S & $\log \mathrm{CFU}=$ & $.52+4$ & $9^{-4}$ Upw4 & & & \\
\hline \multicolumn{7}{|l|}{ (B) } \\
\hline $\log \mathrm{TC}$ & 0.618 & 0.000 & & & & \\
\hline$\sigma_{1}$ & 0.513 & 0.001 & & & & \\
\hline logCyan & -0.416 & 0.006 & & & & \\
\hline $\log \mathrm{HPF}$ & & & 0.528 & 0.052 & & \\
\hline Upw4 & & & & & 0.665 & 0.001 \\
\hline \multicolumn{7}{|c|}{ Regression equations: } \\
\hline $\begin{array}{l}W \text { and } S \\
S\end{array}$ & $\begin{array}{l}\log C F U= \\
\log C F U=\end{array}$ & $\begin{array}{l}6.45+1 \\
.52+4 .\end{array}$ & $\begin{array}{l}g T C+0 \\
)^{-4} \text { Upw4 }\end{array}$ & $\sigma_{t}-0.4$ & yan & $\begin{array}{l}=0.58 \\
=0.44\end{array}$ \\
\hline
\end{tabular}


and were identified at the very good (VGI) or excellent (EI) level (\% i.d. $\geq$ 99.0, $\mathrm{T} \geq 0.5$ and $\%$ i.d. $\geq 99.9, \mathrm{~T} \geq 0.75$, respectively).

All or most bacterial isolates that were tested with the API Zym system (Fig. 4) catalysed the liberation of free inorganic phosphate from organic phosphate esters in alkaline (Bph) or acid $\mathrm{pH}(\mathrm{Aph})$. In the majority of isolates, the specific aminopeptidases, leucine-, valine- and cystine-aminopeptidases (Leu, Val, Cys) were also recorded. The latter 2 have so far been considered to occur according to Turkiewicz (pers. comm.) only rarely in bacteria. In 20 isolates, 2 endoproteases displaying similar specificity for the substrate as animal trypsin (Try) and chymotrypsin (Chy) were recorded. So far (according to Turkiewicz pers. comm.), trypsin-like enzymes were found only among the Streptomyces. There was a slightly lower incidence of glycoside hydro-
Table 4. Multiple stepwise regression between logCFU and (A) physical and (B) physical and biological variables in the bottom water in the Ría de Vigo (Stn 3b). Results are presented for data collected during the full period of this study (Winter [W] and Summer [S], $n=34$ ) and separately for $W(n=14$ ) and $S(n=20)$. ( $\beta)$ Standardised coefficient of regression and $(p)$ level of significance of the slopes in the regression equations. Physical variables: $\sigma_{1}$ (seawater density), Qr4 (runoff), Qs4 (solar radiation) and ${ }^{\circ} \mathrm{C}$ (seawater temperature)

\begin{tabular}{|c|c|c|c|c|c|c|}
\hline \multirow{2}{*}{ Variable } & \multicolumn{2}{|c|}{$W$ and $S$} & \multicolumn{2}{|l|}{ W } & \multicolumn{2}{|c|}{$\mathrm{S}$} \\
\hline & $\beta$ & $\mathrm{p}$ & $\beta$ & $\mathrm{p}$ & $\beta$ & $\mathrm{p}$ \\
\hline \multicolumn{7}{|l|}{ (A) } \\
\hline$\sigma_{1}$ & -0.591 & 0.017 & & & & \\
\hline Qr4 & -0.495 & 0.042 & & & & \\
\hline Qs4 & & & -0.512 & 0.061 & & \\
\hline${ }^{\circ} \mathrm{C}$ & & & & & 0.599 & 0.005 \\
\hline \multicolumn{7}{|c|}{ Regression equations: } \\
\hline$W$ and $S$ & $\log C F U=$ & $28.06-0$ & -0.01 Qr4 & $r^{2}=0.17$ & & \\
\hline $\mathrm{S}$ & $\log C F U=$ & $-3.52+c$ & & $r^{2}=0.36$ & & \\
\hline \multicolumn{7}{|l|}{ (B) } \\
\hline$\sigma_{1}$ & -0.591 & 0.017 & & & & \\
\hline Qr4 & -0.495 & 0.042 & -0.556 & 0.06 & & \\
\hline Q54 & & & -0.503 & 0.08 & & \\
\hline${ }^{\circ} \mathrm{C}$ & & & & & 0.599 & 0.005 \\
\hline \multicolumn{7}{|c|}{ Regression equations: } \\
\hline $\mathrm{W}$ and $\mathrm{S}$ & $\log C F U=$ & $8.06-0$ & $-0.01 Q r 4$ & $\mathrm{r}^{2}=0.17$ & & \\
\hline $\mathrm{S}$ & $\log C F U=$ & $-3.52+c$ & & $r^{2}=0.36$ & & \\
\hline
\end{tabular}

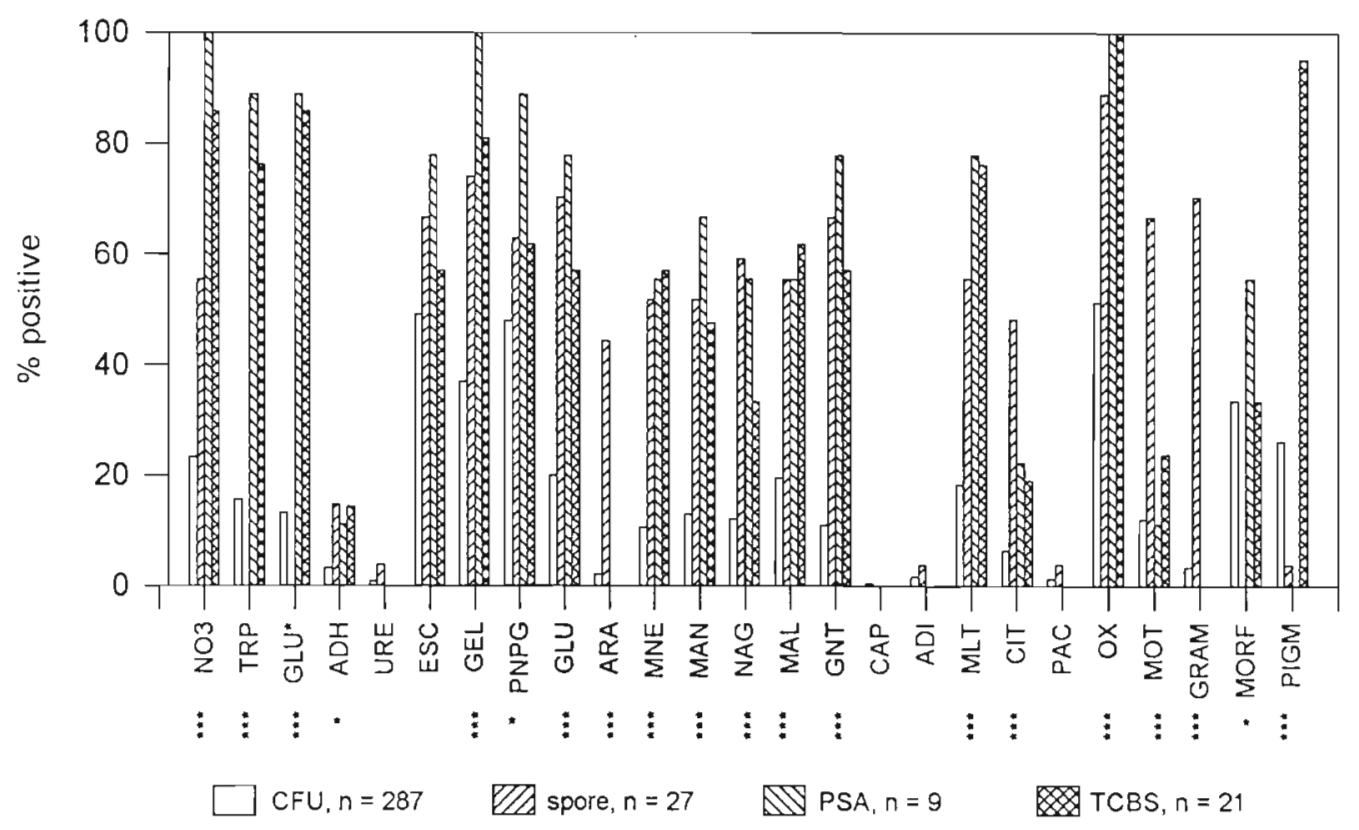

Fig. 3. Comparison of responses in API 20NE of CFU bacteria isolated on marine agar (CFU) and between spore-forming bacteria (CFUs), and Pseudomonas (PSA) and Vibrio (TCBS) on selective media. The following tests were conducted: (1) API $20 \mathrm{NE}$ conventional tests; reduction of nitrates to nitrites $\left(\mathrm{NO}_{3}\right)$, indole production (TRP), fermentation of glucose (GLU $)$, arginine dihydrolase (ADH), urease (URE), $\beta$-glucosidase (ESC), gelatin hydrolysis (GEL), $\beta$-galactosidase (PNPG). (2) API 20NE assimilation tests of; glucose (GLU), arabinose (ARA), mannose (MNE), mannitol (MAN), N-acetyl- $\beta$-D-glucosamine (NAG), maltose (MAL), gluconate (GNT), caprate (CAP), adipate (ADI), malate (MLT), citrate (CIT), phenyl-acetate (PAC). (3) Cytochrome oxidase test [OX]. (4) Classical tests: motility (MOT); Gram reaction (GRAM); cocci (MORF); pigmented colonies (PIGM). Significance level $(* p<0.05, \cdots p<0.01, \cdots p<0.001)$ between the frequency of positive responses shown by each population $\left(\chi^{2}\right)$ 


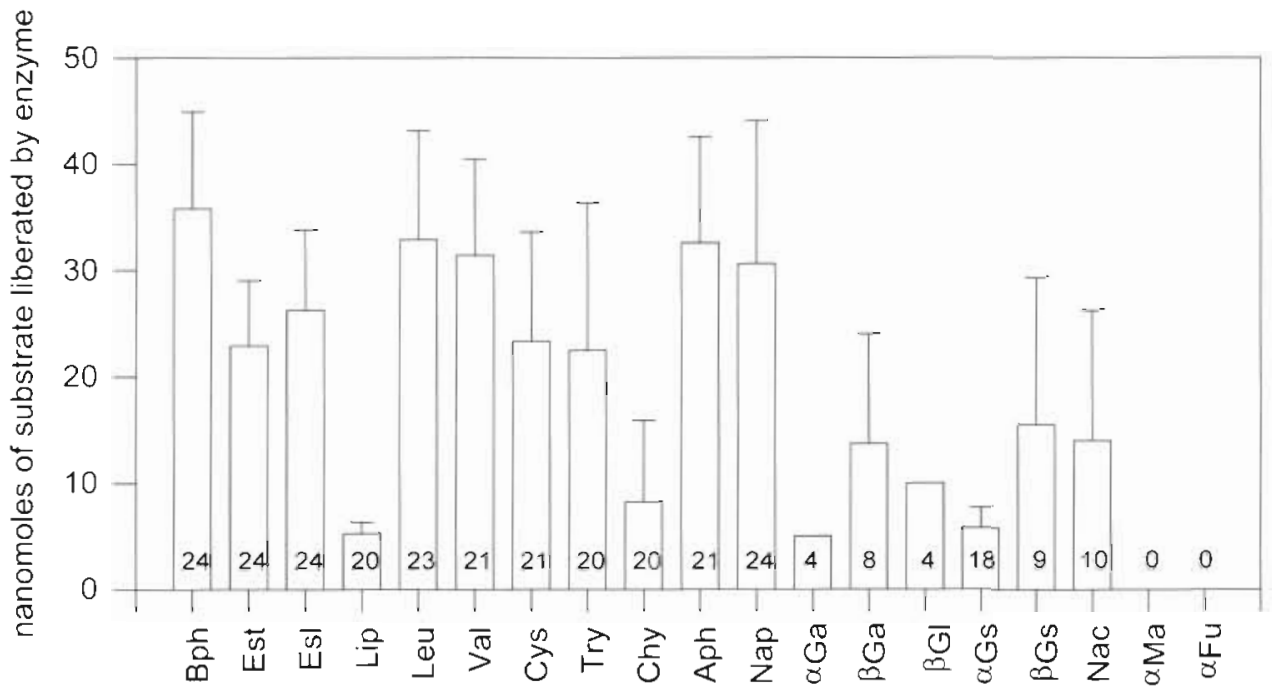

Fig. 4. Constitutive enzyme activities displayed by CFU bacteria from the Ría de Vigo described by the semi-quantitative API Zym system. Activities are expressed as nanomoles of substrate hydrolysed by a bacterial inoculum of standard turbidity $\left(10^{8}\right.$ cells $\left.65 \mathrm{\mu l}^{-1}\right)$ and presented as an average $(+\mathrm{SD})$ of activities for that enzyme. The figure in each bar gives the number of isolates $(\Sigma=24)$ showing liberation of between 5 and $40 \mathrm{nmol}$ of substrate. The highest activity estimated by this system is $40 \mathrm{nmol}$

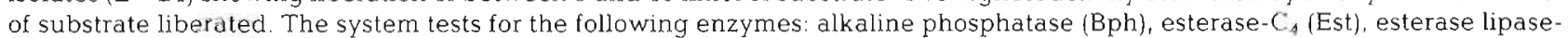
$\mathrm{C}_{8}$ (Esl), lipase- $\mathrm{C}_{14}$ (Lip), leucine arylamidase (Leu), valine arylamidase (Val), cystine arylamidase (Cys), trypsin (Try), chymotrypsin (Chy), acid phosphatase (Aph), naphthol-AS-BI-phosphohydrolase (Nap), $\alpha$-galactosidase ( $\alpha \mathrm{Ga}), \beta$-galactosidase $(\beta \mathrm{Ga}), \beta$-glucuronidase $(\beta \mathrm{Gl}), \alpha$-glucosidase $(\alpha \mathrm{Gs}), \beta$-glucosidase $(\beta \mathrm{Gs}), N$-acetyl- $\beta$-glucosaminidase (Nac), $\alpha$-mannosidase $(\alpha \mathrm{Ma}), \alpha$-fucosidase ( $\alpha F u$ )

lases, although among these, $\beta$-galactosidase $(\beta \mathrm{Ga})$, $\beta$ glucosidase ( $\beta G$ s) and $N$-acetyl- $\beta$-D-glucosaminidase (Nac) were most prominent. The latter cleaves glucoside bonds in chitobiose and some by-products of the partial hydrolysis of chitin. Lipolytic activity against long-chain fatty acids, lipase- $\mathrm{C}_{14}$ (Lip) was lower than that of caprylate esterase lipase- $\mathrm{C}_{8}$ (Esl) and butyrate esterase- $\mathrm{C}_{4}$ (Est) against lipids short-chain fatty acids. Neutral fats in nature are composed of fatty acids, which vary in chain length. Neutral fats occur frequently in aquatic plant material and are available for bacterial decomposition. Isolates described in this work exhibited highest activity against neutral fats comprising short-chain fatty acids.

\section{Comparison of CFU bacterial populations in time and depth}

We compared bacterial cultures derived from Expts 7 and 13 by selecting from the different media 1 distinct colony representing each colony group. Within each of these 'groups' the number of similar colonies ranged from 1 to several score. In pure culture, colonies were described in terms of size, colour, opacity, elevation, margin, and consistency. The total number of isolates selected for passage through API 20NE from each experiment reflected diversity within the population. In this respect, diversity in Expt 13 was higher by a fac- tor of 2 than in Expt 7. The frequency of positive responses was also higher in Expt 13 than in Expt 7 (Fig. 5). Isolates from Expt 13 showed higher frequency of positive responses in 17 of a total of 25 tests; among them 6 tests were statistically significant (Fig. 5).

The average frequency of positive responses to the API 20NE system from surface, middle and bottom layers in Expt 7 were 18.1, 19.6, and $22.3 \%$ respectively (Fig. 6a). Significant differences between surface and bottom populations were recorded in 5 tests: $\mathrm{NO}_{3}$, TRP, $\mathrm{GLU}^{\bullet}, \mathrm{GEL}\left(\chi^{2}{ }_{1}=19.1,28,24,11\right.$ respectively, $\mathrm{p}<0.001$ in each case), and MLT $\left(\chi^{2}{ }_{1}=8.05, p<0.01\right)$. Positive responses were more prominent in those samples from the bottom water. The frequency of positive responses for bacterial populations in the surface and middle layers were more similar. The bacterial population from the greatest depth then, despite its low numbers, exhibited the broadest capacity to metabolise the substrates presented in the API 20NE system. In Expt 13, bacteria from each layer (surface, middle and bottom) showed more positive reactions (average 30.1, 22.9 and $30.3 \%$ respectively) than those in Expt 7 (Fig. 6b). A different pattern to that in Expt 7 was noted in Expt 13. Maximum percentage of positive reactions were found both at the bottom and at the surface, and the minimum in the middle layer $(-15 \mathrm{~m}$ depth, bottom of the photic zone). Differences in the frequency of positive responses were significant between the bottom and middle layers, being more prominent in bac- 


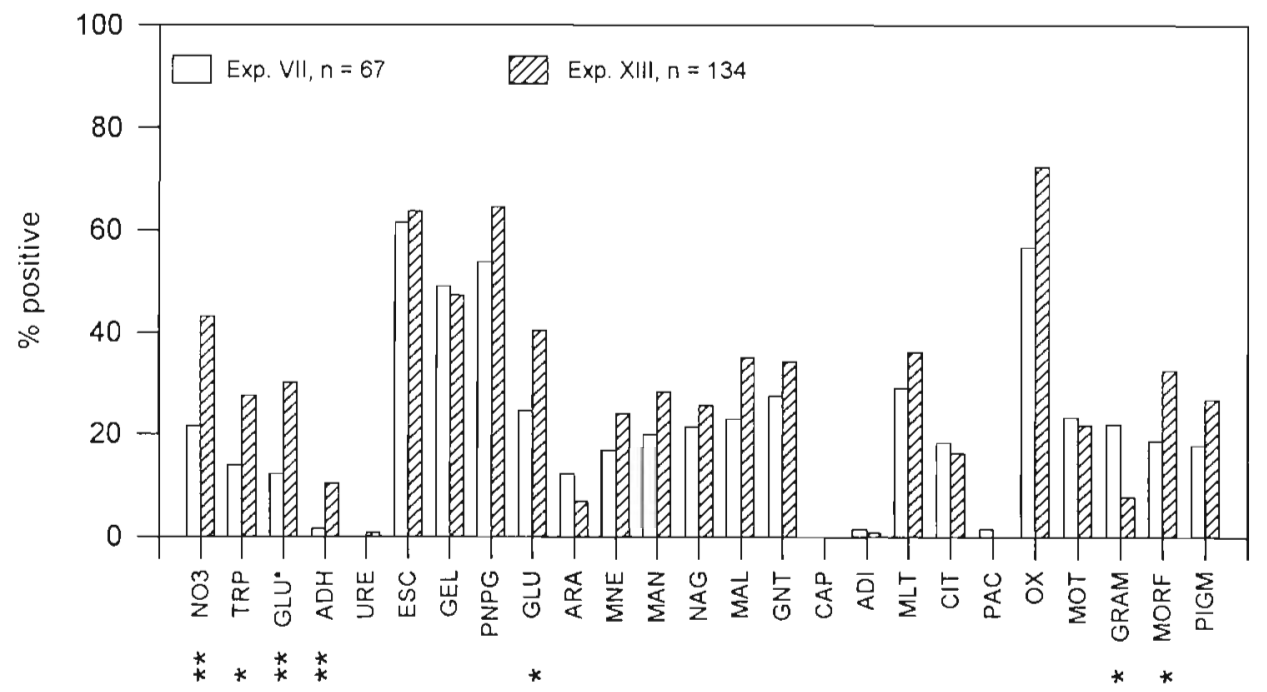

Fig. 5. Differences between CFU bacteria isolated from the Ría de Vigo water column (Stn 3b) in 2 experiments (Expt 7 [10 December 1990] and Expt 13 [14 February 1991]) in terms of percentage of positive responses shown in the API 20NE system and classical tests. Tests are described in Fig. 3. Significance level $(" p<0.05, \cdots p<0.01)$ between the frequency of positive responses shown by each population $\left(\chi^{2}{ }_{1}\right)$
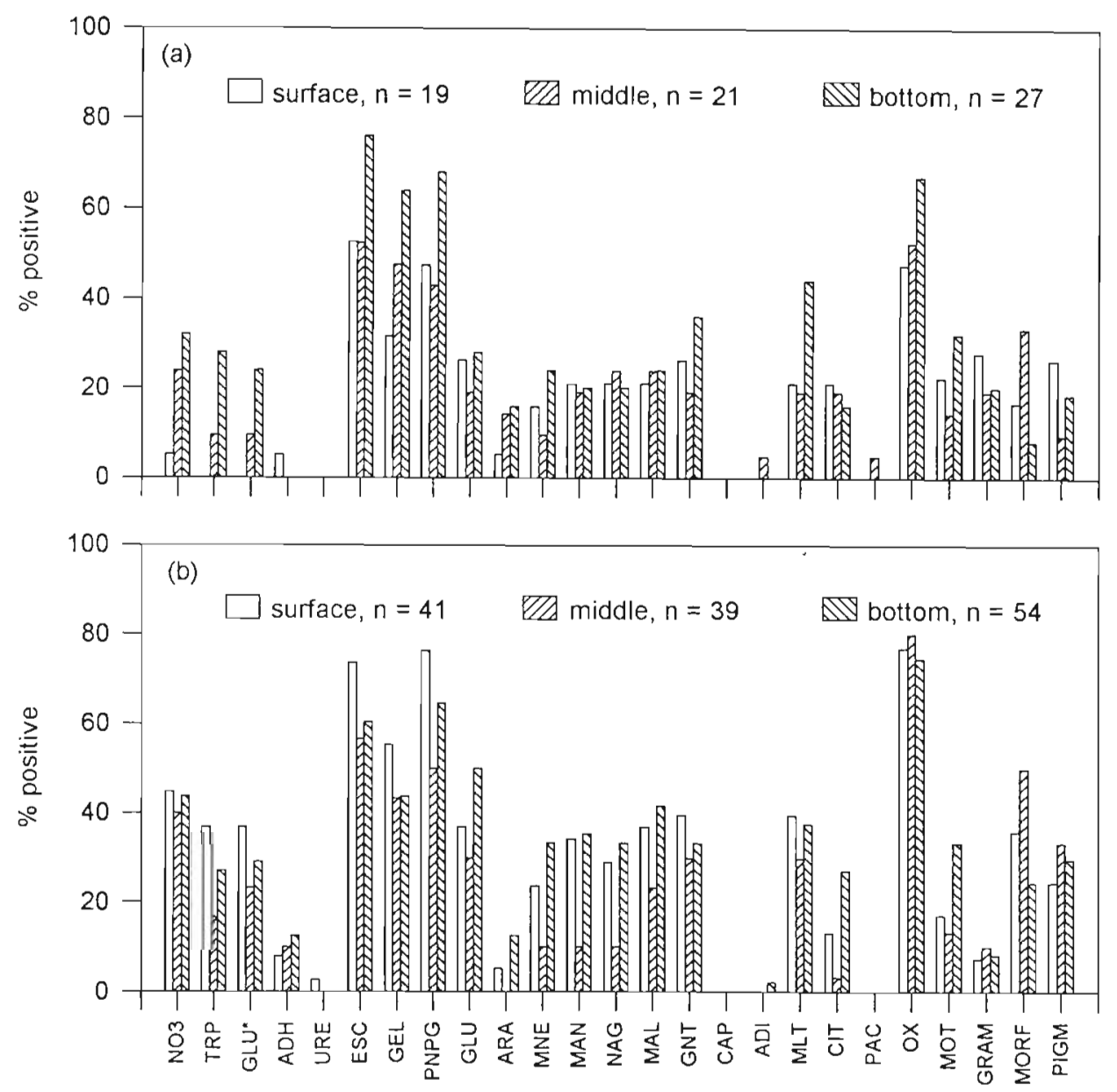

Fig. 6. Comparison of responses in API 20NE of CFU bacteria isolated from 3 depths. (a) Expt 7 (December 10 ); (b) Expt 13 (February 14). Tests are described in Fig. 3. Significant differences between depths are described in the text (see 'Results') 


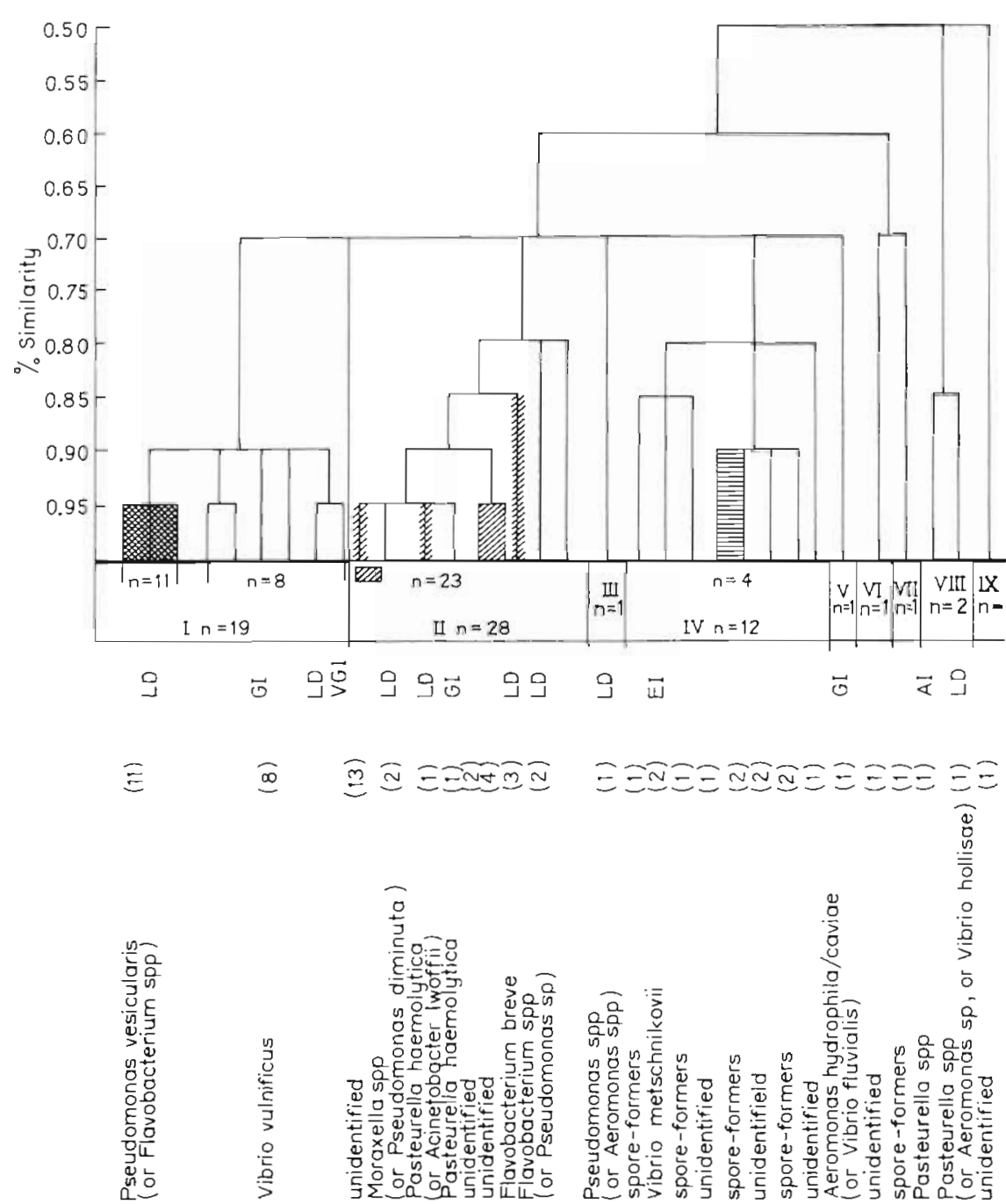

Fig. 7. Hierarchical classification of 67 isolates of CFU bacteria from the Ría de Vigo water column (Stn 3b) on December 10 (Expt 7) computed on the basis of responses of isolates to 25 API $20 \mathrm{NE}$ and classical tests. Identification confidence was described as: excellent (El), very good (VGI), good (GI), acceptable (AI), low confidence (LD). In brackets, numbers of isolates sharing the same or very similar numerical profile. Note that some isolates in groups with the same numerical profile but with different colony morphology on nutrient agar were considered distinct during initial selection for this analysis. Furthermore, some apparently identical species have different physiological/biochemical and numerical profiles, and are therefore located in different clusters

larity between both groups of tests from Expts 7 (mostly conventional tests) and 13 (mostly assimilation tests), which displayed significant differences between layers, were observed.

\section{Bacterial identification}

In the cluster analysis comprising isolates from Expts 7 and 13, 94\% ( $n=171)$ of isolates clustered at a similarity level $\geq 80 \%$ on the basis of their responses to the 21 tests in API $20 \mathrm{NE}$ and to the 4 classical. tests (Figs. 7 \& 8).

Four clusters containing 2 to 28 isolates and 5 unclustered isolates were defined at $80 \%$ similarity level in Expt 7 (Fig. 7). Using the API 20NE Analytical Profile Index $51 \%$ isolates in Expt 7 were identified to the taxon, species or genus level, or provisionally with low confidence (LD) to any of several taxa belonging to different genera. The remaining $49 \%$ of isolates had numerical profiles that could not affect identification through the API. Seven clusters containing 2 to 55 isolates and 5 unclustered isolates were described at the 80\% similarity level in Expt 13 (Fig. 8). The percentage of isolates identified in Expt 13 was $61 \%$. The numerical profiles of the remaining $39 \%$ isolates were insufficient for identification.

The results of the cluster analysis shows that taxonomic differences between bacterial cultures from Ría de Vigo in both experiments were considerable and that bacterial populations in Expt 13 were more diverse than in Expt 7 Eleven isolates in Cluster I from Expt 7 shared the same numerical profile (identification) and location as 17 isolates in Cluster I from Expt 13. Conversely, in Expt 7, 23 isolates from

teria from the bottom layer. These differences were in the numbers of bacterial cultures that assimilated ARA, MNE, MAN, NAG and CIT $\left(\chi^{2}{ }_{1}=12.5,12.62\right.$, $14.21,12.63,18.6$, where $p<0.001)$. Motile bacteria were also more common in the deeper water (MOT, $\chi_{1}^{2}=8.58, p<0.01$ ). The frequency of assimilation of ARA, MNE, MAN, NAG, and CIT also varied significantly between bacteria from the middle and surface layers $\left(\chi^{2}{ }_{1}=5.3, p<0.05 ; 5.6, p<0.05 ; 1.3 .2, p<0.01\right.$; $9.18, p<0.05 ; 5.94, p<0.05)$. No coincidences in simi-
Cluster 2 shared the same numerical profile but different location as 22 isolates in Cluster 6 and 9 isolates in Cluster 7 from Expt 13. Additionally, 4 isolates from Cluster 4 in Expt 7 shared the same numerical profile but different location as 3 isolates (Cluster 3) from Expt 13. Bacterial isolates used in the cluster analysis provided 96 distinct biochemical profiles. Additional micro- and macroscopic analyses of bacterial cultures indicated that some with the same profiles were not necessarily of the same species, so the number of dis- 


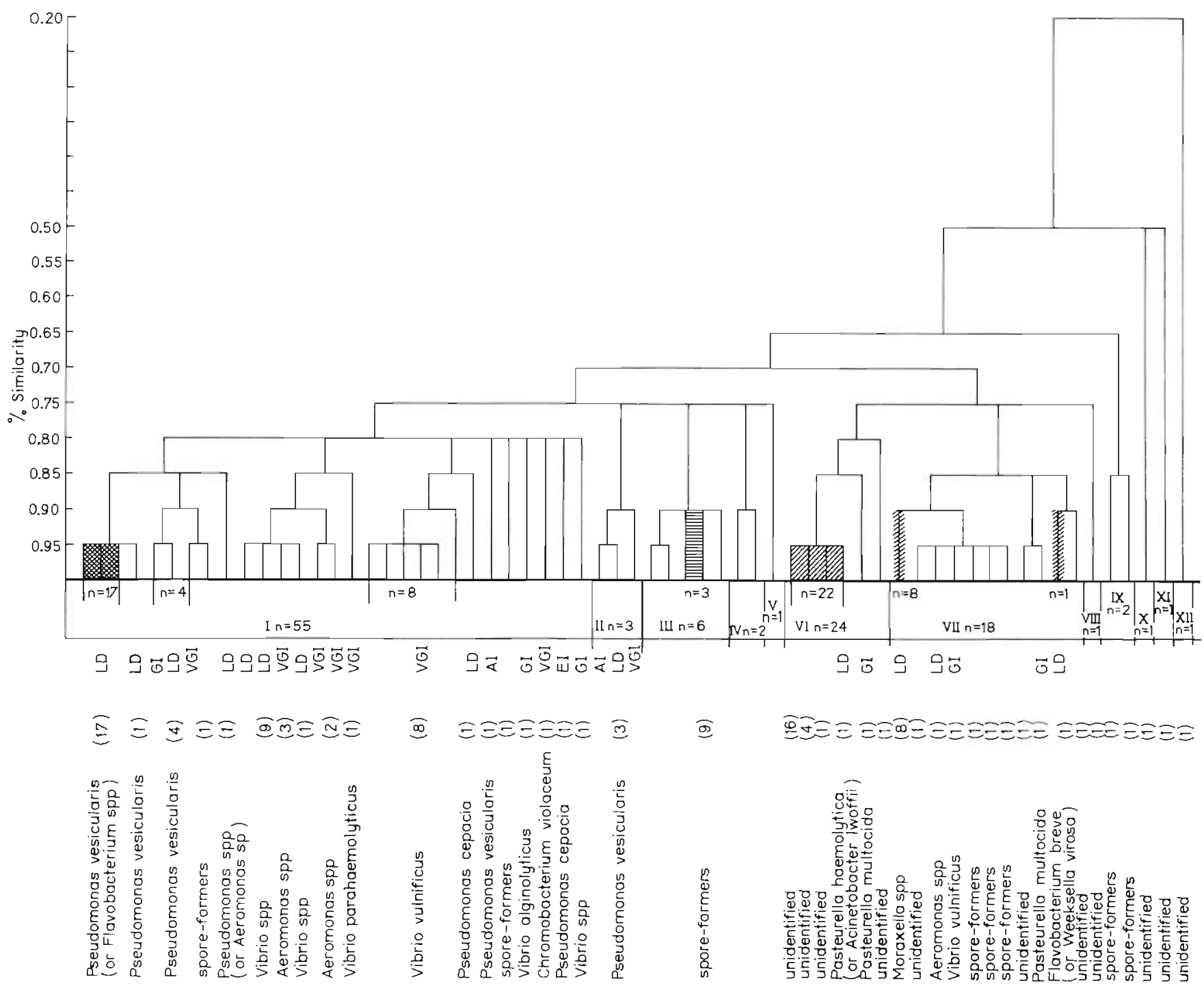

Fig. 8. Hierarchical classification of 115 isolates of CFU bacteria from the Ría de Vigo water column (Stn 3b. Expt 13 [February 14]). Identification confidence was described as: excellent (EI), very good (VGI), good (GI), acceptable (AI), low confidence (LD). In brackets, numbers of isolates sharing the same or very similar numerical profile. Note differences in location between isolates sharing the same numerical profiles (with the same pattern of bars) in Expts 7 and 13

tinct groups was larger. As shown in Figs. 7 \& 8, more isolates were unidentified in Expt $7(49 \%)$ than in Expt $13(39 \%)$.

\section{DISCUSSION}

\section{Physical and biological control of CFU populations}

Between October 1990 and August 1991 we counted CFU bacteria at the centre of Ría de Vigo, and compared counts with total bacterioplankton and other biological and hydrological variables. CFU formed only a small fraction of the total bacterioplankton in the
Ría de Vigo. The most obvious habitat for these bacteria in a metabolically active state is in association with POM, which is more abundant in the vicinity of land (Ducklow \& Shiah 1993). Even if the CFU fraction is not exclusively dependent on POM, it is likely that these bacteria are the most suited and preparec among the total bacteria for colonising particulate matter (Zdanowski 1995). Their intense hydrolytic activity on marine aggregates produces a rapid particle solution (Smith et al. 1992). These latter authors hypothesise that hydrolytic enzymes (surface bound and released enzymes of the attached bacteria) are responsible for large-scale transfer of organic matter from sinking particles to the dissolved phase. They also reported short 
turnover time of 0.2 to $2.1 \mathrm{~d}$ in the case of particulate amino acids and it must be considered that most of our CFU bacterial fraction displayed high peptide hydrolytic activity as well as esterase lipase, ESC and PNPG activity (cf. Figs. 4 \& 6). Such high hydrolytic activity might be especially essential in the case when these bacterial populations colonise particles.

The amount of POM in coastal waters generally exceeds by 1 to 2 orders that in oceanic waters (Parsons 1975, Williams 1975). In Galician estuarine upwelling ecosystems, POC reaches maximal values of $80.2 \mu \mathrm{mol}$ $\mathrm{C} \mathrm{kg}^{-1}$ (Rosón et al. 1995) or more (Fraga 1960) and thus attains levels equivalent to that of DOM (Doval et al. 1997). The principal source of suspended POM in estuaries such as the Ría de Vigo is, apart from phytoplankton (Fraga 1960, Alvarez-Salgado et al. 1997), also that derived from highly productive benthic macrophytes. At least half of the total $176 \mathrm{~km}^{2}$ of the Ria's bottom is less than $20 \mathrm{~m}$ deep (Fig. 1), and as a consequence of which solar irradiance can reach kelp-beds. In similarly temperate coastal seawaters throughout the world, seaweed primary production may surpass that of the phytoplankton (Mann 1973). This phenomenon was also noted in cold Antarctic coastal seawaters (Dawson et al. 1985, Reichardt \& Dieckmann 1985). Note that primary production by benthic macroalgae can continue beyond summer and the phytoplankton bloom. Throughout this study, but especially after spring storms, large quantities of macrophytes were seen floating in the water or on the shore. Another important POM source can be animal remains and faeces (Sieburth et al. 1974). Ageing and disrupted plant or animal tissues or cells are colonised by epibacteria and transformed to detritus. In this way bacteria serve as the primary source of carbon, nitrogen, amino acids and energy for detritivores.

Compared to the relatively small fluctuations in the total bacterial counts (coefficient of variation ranged from 11.7 to $56.3 \%$, see Zdanowski \& Figueiras 1997), the fluctuations in the number of CFU bacteria in the Ría de Vigo were considerably greater (coefficients of variation of 112 and $113 \%$ at the surface and in the middle layer respectively, and $233 \%$ in bottom water). This divergence between CFU and DAPI-TC was much higher than that reported for other bays, for example the Kiel Bight (Rheinheimer 1977, Zimmermann 1977) and must have a specific origin. At the moment explanations can be only hypothetical, but the results of multiple stepwise regression analysis (Tables 2 to 4) can help to clarify this divergence. In surface and bottom waters only physical variables were related with CFU counts during summer. Upwelling was the most important factor in the surface layer while in the bottom layer temperature was dominat. Both physical factors appeared to act on CFU populations in a different way. In surface waters, upwelling, which brings cold nutrient rich waters to the surface, stimulates phytoplankton growth and consequently the synthesis of POM that is a source of food for CFU bacteria. In bottom waters, bacterial growth must be stimulated by slight rises of temperature. Therefore, summer variations in CFU bacteria in surface and bottom waters are opposite. Upwelled cold waters favour CFU increases in the surface but not CFU growth in the bottom. The converse must occur during stratification. Over the whole sampling period only in the surface layer was a relatively strong relationship between CFU counts and physical variables found $\left(r^{2}=0.42\right.$ in the surface layer against $r^{2}=0.17$ in the bottom layer; Tables 2 \& 4). Seasonal variability due to increases in incoming solar radiation is the most important physical factor, which is reflected in the seasonal variation in seawater temperature and primary production (Alvarez-Salgado et al. 1996, Zdanowski \& Figueiras 1997). Within this general pattern of increasing solar radiation and temperature, summer upwelling bringing deep, cold water to the surface had a diluting effect that is expressed in the negative term of temperature in the equation.

Physical variables in the middle layer could explain up to $43 \%$ of the variability in CFU counts during the summer period. However, contrary to observations in the surface and bottom layers, the inclusion here of biological variables in the regression analysis raised the explained variance considerably, especially for the whole sampling period (Table 3). A similar situation of higher biological control on total bacterioplankton variability was previously observed in the Ría de Vigo (Zdanowski \& Figueiras 1997). Three physical variables (runoff, upwelling and solar radiation) were significant in controlling the CFU population, but runoff and upwelling were the most important (Table 3 ). The 3 variables lowered CFU numbers in the middle layer. Strong runoff events can directly influence the middle layer by diluting the CFU population and also by removing POM from the upper layers, thus precluding its introduction to deeper water. On the other hand, slight upwelling events can easily reach the bottom of the photic layer, and therefore, dilute the CFU population by mixing with the upwelled water. It is more difficult to find a satisfactory explanation for the negative effect of solar radiation $i$ perhaps an indirect action should be sought. Solar radiation promotes phytoplankton growth (chl a vs Qs4, $\mathrm{r}^{2}=0.56$, $p<0.001$ ) and the growth of CFU bacteria occurs by colonising particles prior to their dispersal into the surrounding water. Therefore a negative relationship between Qs4 and/or chl a with logCFU (Table 3) should be expected when studying the free-stage of CFU bacteria. In light of this interpretation, the CFU peak on 15 April (Fig. 2, Table 1) can be considered as derived 
from the decomposition of the mid-April phytoplankton bloom (see Fig. 5 in Zdanowski \& Figueiras 1997). On the other hand, during studies on Antarctic krill Euphausia superba degradation in Antarctica, Zdanowski (1995) observed that CFU bacterial numbers in the water column increased by 2 orders of magnitude following the sudden disappearance of high concentrations of krill in Admiralty Bay (King George Island). In each of these terms, the free-living CFU fraction seems to be an indicator of some aspect of microbial degradation of suspended matter (Kriss 1963). The negative relationship between logCFU and chlorophyll in the middle layer (Table 3) can be considered a consequence of coastal upwelling, especially during summer when more phytoplankton blooms occur (Rosón et al. 1995, AlvarezSalgado et al. 1996).

The consideration of biological variables in the regression equations for this middle layer considerably increased the explained variance in CFU counts (Table 3), especially for the whole period (up to $61 \%$ ). The negative relationship between CFU and chlorophyll was considered above. Connected with this interpretation is the positive relationship between total bacterioplankton (TC) and CFU; the release to the surrounding water of the CFU attached to the particles after decomposition of POM will increase the numbers of TC. The dilution effect of runoff (Qr4) and the negative indirect action of solar radiation (Qs4) remain in the equation for the whole sampled period (winter and summer)

We hypothesise that 3 physical factors are prominent in the control of CFU standing stock in the Ría de Vigo. Incoming solar radiation and upwelling stimulate the development of POM in surface waters that will be a source of food for these bacteria, and terrestrial runoff negatively affects their numbers through dilution, mainly in the middle layer. Nevertheless, in the middle layers of the water column (bottom of the photic layer) a lag between the synthesis of POM and CFU abundance exists. Synthesis of POM promoted by solar radiation and upwelling occurs in the surface layer and then partially sinks to deeper layers. These lags at the bottom of the photic layer are presumably due to the fact that CFU, which are attached to particles, will be released to the surrounding water after POM decomposition during sinking. The existences of these lags are important in understanding the CFU variability in upwelling systems.

\section{Diversity of CFU bacteria and their ecophysiological responses}

Bacterial isolates from Expts 7 and 13, which corresponded to 2 contrasting hydrographic situations, con- firmed the existence of different CFU communities at the same station at different times with distinct hydrological conditions (Table 1). Despite the enhancement of CFU by moderate upwelling, during that period in which the second strongest upwelling occurred, CFU numbers decreased 10 December, see Fig. 3d in Zdanowski \& Figueiras 1997). This event reduced CFU numbers by a factor of 3 whilst DAPI-TC numbers remained stable (Table 1). This may indicate that upwelled waters low in POM are also low in CFU, but not in the total bacterial fraction. Bacterial isolates (CFU bacteria) from this event (Expt 7) passed through the API systems were different in physiological terms to those isolated during Expt 13 (Figs. 7 \& 8), when upwelling was lower and runoff was higher.

On the basis of recent studies of CFU isolated from different Antarctic soils (Zdanowski \& Weglenski unpubl. data) and comparison of their responses in the API 20NE system with Antarctic marine CFU bacteria (Zdanowski \& Donachie 1993), we can confirm Gray \& Williams's (1971) suggestion that soil bacteria must respond to the multiplicity of microhabitats in the soil in order to survive and exhibit more variability than bacteria in water habitats since the former display a much broader range of responses in this diagnostic system. CFU bacteria in areas with high levels of POM (e.g. soil, krill digestive tract and sea ice) have generally shown more positive responses in the API 20NE system. We showed that differences between CFU bacterial populations isolated in Expts 7 and 13 were attributable to the different hydro- and meteorological pressures that prevailed during each of these. Lower CFU counts, diversity, and the lower number of positive responses in API $20 \mathrm{NE}$ of bacteria from Expt 7 reflected the strong upwelling and NW winds that introduced CFU poor water masses from the ocean into the Ría de Vigo. Conversely, fairly high runoff and NE winds during Expt 13 enriched the surface population at the center of the estuary with CFU bacteria of terrestrial origin or those from shallow inner waters of the Ría de Vigo. These were characterised by their higher numbers of positive responses in API 20NE and by higher CFU counts.

None of the 12 carbohydrates (including glucose) presented in the assimilation tests (API 20NE) as sole carbon sources proved to be a preferred source. Microbiologists use the rate of uptake of labelled glucose as an index of bacterial activity, presuming that all bacteria take it up. Our finding that as many as $73 \%$ of the CFU population did not assimilate glucose agrees with that of Hanson \& Wiebe (1977). These authors also noted that many marine bacteria do not utilize glucose, or do so at very low rates.

Additional information on specific bacterial groups within the CFU fraction, through the use of selective 
media (for Pseudomonas, Vibrio and sporeformers), we found that this fraction has an indicator value for the estuary's sanitary status. Although no pathogenic Enterobacteriaceae species were identified, we did isolate $V$. vulnificus and/or V. parahaemolyticus, both of which can cause infection through consumption of contaminated seafood. It should be noted, however, that owing to the considerable hydrographic variability in the Ría de Vigo, and particularly to intensive exchange of estuarine water with the ocean, these pathogenic bacteria did not constitute a health hazard during this study. Conversely, through Vibrio, Pseudomonas or sporeformers' capacity to utilise a broad range of substrates and their rapid growth on surfaces, and despite their very low numbers (usually $<1 \%$ of total $\mathrm{CFU}$ ) these groups may be important in the colonisation and decomposition of POM in the Ría de Vigo.

Acknowledgements. We thank our colleagues from the Instituto de Investigacións Mariñas who participated in the sampling. We are also very grateful to A. M. Mosquera for her work with DAPI and ciliate counts, and to Dr S. P. Donachie for checking the English. This study was supported by the European Union's MAST project, contract MAST-CT90-0017 M.K.Z. thanks the 'Ministerio de Educación y Ciencia and Ministerio de Asuntos Exteriores' in Spain for the financial support that enabled him to conduct this research in Vigo during 1990-1991.

\section{LITERATURE CITED}

Alvarez-Salgado XA, Rosón G, Pérez FF, Pazos Y (1993) Hydrographic variability off the Rías Baixas (NW Spain) during the upwelling season. J Geophys Res 98: $14447-14455$

Alvarez-Salgado XA, Rosón G, Pérez FF, Figueiras FG, Ríos AF (1996) Nitrogen cycling in an estuarine upwelling system, the Ría de Arousa (NW Spain). II. Spatial. differences in the short-time-scale evolution of fluxes and net budgets. Mar Ecol Prog Ser 135:275-288

Alvarez-Salgado XA, Castro CG, Pérez FF, Fraga F (1997) Nutrient mineralization patterns in shelf waters of the western Iberian upwelling. Cont Shelf Res 17:1247-1270

Bakun A (1973) Coastal upwelling indices, west coast of North America 1946-71. NOAA Terh Rep NMFS SSRF671. US Dept of Commerce, Seattle

bioMerieux (1990a) Analytical Profile Index. API $20 \mathrm{NE}$. Marcy-l'Etoile, Lyon

bioMerieux (1990b) Analytical Profile Index. API RapiD 20E. Marcy-l'Etoile, Lyon

Bouvy M, Delille D (1987) Numerical taxonomy of bacterial communities associated with a subantarctic mussel bed. Helgol Wiss Meeresunters 41:415-424

Davis PG, Sieburth JMCN (1982) Differentiation of phototrophic and heterotrophic nanoplankton populations in marine waters by epifluorescence microscopy. Ann Inst Oceanogr 58:249-260

Dawson R, Schramm W, Bolter M (1985) Factors influencing the production, decomposition and distribution of organic and inorganic matter in Admiralty Bay, King George Island. In: Siegfried WR, Condy PR, Laws RM (eds)
Antarctic nutrients cycles and food webs. Springer-Verlag, Berlin, p 1.09-114

Dietrich G, Kalle K, Krauss W, Siedler G (1980) General oceanography: an introduction, 2nd edn. J Wiley \& Sons, New York

Donachie SP, Zdanowski MK (1998) Potential digestive function of bacteria in krill Euphausia superba stomachs. Aquat Microb Ecol 14:129-136

Donachie SP, Saborowski R, Peters G, Buchholz F (1995) Bacterial digestive enzyme activity in the stomach and hepatopancreas of Meganyctiphanes norvegica (M. Sars 1857). J Exp Mar Biol Ecol 188:151-165

Doval MD, Alvarez-Salgado XA, Pérez FF (1997) Dissolved organic matter in a temperate embayment affected by coastal upwelling. Mar Ecol Prog Ser 157:21-37

Ducklow HW, Shiah FK (1993) Bacterial production in estuaries. In: Ford TE (ed) Microbiology: an ecological approach. Blackwell Scientific Publications, Oxford, p 261-287

Fenchel T, Hemmingsen BB (1974) Manual of microbial ecology. Akademisk Forlag

Fermin EG, Figueiras FG, Arbones B, Villarino ML (1996) Short-time scale development of a Gymnodinium catenatum population in the Ría de Vigo (NW Spain). J Phycol 32: 212-221

Figueiras FG, Jones KJ, Mosquera AM, Alvarez-Salgado XA, Edwards A, MacDougall N (1994) Red tide assemblage formation in an estuarine upwelling ecosystem: Ría de Vigo. J Plankton Res 16:857-878

Fraga F (1960) Variación estacional de la materia orgánica suspendida y disuelta en la Ría de Vigo. Influencia de la luz y la temperatura. Invest Pesq 17:127-140

Fraga $F$ (1967) Hidrografía de la ría de Vigo, 1962, con especial referencia a los compuestos de nitrogeno. Invest Pesq 31:145-1.59

Fraga F, Margalef R (1979) Las rías gallegas. Estudio y explotación del mar en Galicia. Cursos y congresos, University of Santiago, p 101-121

Geiss HK, Piotrowski HD, Hingst V (1985) Evaluation of API $20 \mathrm{NE}$ in routine diagnostics of nonfermenting Gramnegative rod-shaped bacteria. Zbl Bakt Mikrobiol. Hyg A-Med 259:35-42

Gray TRG, Williams ST (1971) Soil micro-organisms. Oliver \& Boyd Ltd, Edinburgh

Hanson RB, Wiebe WJ (1977) Heterotrophic activity associated with particulate size fractions in a Spartina saltmarsh estuary, Sapelo Island, Georgia, USA, and the continental shelf waters. Mar Biol 42:321-330

Harris JM (1993) The presence, nature, and role of gut microflora in aquatic invertebrates: a synthesis. Microb Ecol 25:195-231

Karl DM, Knauer GA (1984) Detritus-microbe interactions in the marine pelagic environment: selected results from the VERTEX experiment. Bull Mar Sci 35:550-565

King EO, Ward MfK, Raney DE (1954) Two simple media for the demonstration of pyocyanin and fluorescin. $J$ Lab Clin Med 44:301-307

Kirchman DL (1993) Particulate detritus and bacteria in marine environments. In: Ford TE (ed) Aquatic Microbiology: an ecological approach. Blackwell Scientific Publications, Boston, p 321-341

Kriss AE (1963) Marine microbiology (deep sea). Oliver \& Boyd Ltd, Edinburgh

Kriss AE, Misustina IE, Lebedeva MN (1969) Plotnost bakterialnogo naselenija (geterotrofov\} v vodnoj tolsce Juznogo i Indi.jskogo okeanov. (Bacterial population densities [heterotrophs] in the water column of the Southern and Indian Oceans). Mikrobiologi.ja 38:511-517 
Mann KH (1973) Seaweeds, their productivity and strategy for growth. Science 182:975-981

Moncoiffe G (1995) The response of microbial plankton photosynthetic, respiration and growth rates to upwelling processes in the Ría de Vigo (NW Spain). PhD thesis, University of Belfast

Parsons TR (1975) Particulate organic matter in the sea. In Riley JP, Skirrow G (eds) Chemical oceanography, Vol 2, 2nd edn. Academic Press, London, p 365-383

Porter KG, Feig YS (1980) The use of DAPI for identifying and counting aquatic microflora. Limnol Oceanogr 25:943-948

Reichardt W, Dieckmann G (1985) Kinetics and trophic role of bacterial degradation of macroalgae in Antarctic coastal waters. In: Siegfried WR, Condy PR, Laws RM (eds) Antarctic nutrients cycles and food webs. Springer-Verlag, Berlin, p 115-122

Rheinheimer G (1977) Regional distribution of saprophytic and coliform bacteria. In: Rheinheimer $G$ (ed) Microbial ecology of brackish water environment. Springer-Verlag, Berlin, p 121-137

Ríos AF, Nombela MA, Pérez FF, Rosón G, Fraga F (1992) Calculation of runoff to an estuary. Ría de Vigo. Sci Mar 56:29-33

Rosón G, Pérez FF, Alvarez-Salgado XA, Figueiras FG (1995) Variation of both thermohaline and chemical properties in an estuarine upwelling ecosystem: Ría de Arousa. I. Time evolution. Estuar Coast Shelf Sci 41:195-213

Sieburth JMcN, Brooks RD, Gessner RV, Thomas CD, Tootle JL (1974) Microbial colonization of marine plant surfaces as observed by scanning electron microscopy. In: Colwell RD, Morita RY (eds) Effect of the ocean environment on microbial activities. University Park Press, Baltimore, p $418-432$

Smith DC, Simon M, Allderedge AL, Azam F (1992) Intense hydrolitic enzyme activity on marine aggregates and implications for rapid particle solution. Nature 359: $139-142$

Sneath PHA, Sokal RR (1974) The principles and practice of numerical classification. Freeman, San Francisco

Sokal RR, Michener CD (1958) A statistical method for evaluating systemating relationships. Univ Kans Sci Bull 38: $1409-1438$

Soutar A, Kling SA, Crill PA, Duffrin E, Bruland KW (1977) Monitoring the marine environment through sedimentation. Nature 266:136-139

Editorial responsibility: Otto Kinne (Editor),

Oldendorf/Luhe, Germany
Tearle PV, Richard KJ (1987) Ecophysiological grouping of Antarctic environmental bacteria by APl $20 \mathrm{NE}$ and fatty acid fingerprints. J Appl Bacteriol 63:497-503

Washington JA II, Warren E, Karlson AG (1972) Stability of barium sulfate turbidity standards. Appl Microbiol 24: 1013

West PA, Ressek E, Brayton PR, Colwell RR (1982) Statistical evaluation of a quality control method for isolation of pathogenic vibrio species on selected thiosulphate citrate - bile - salts - sucrose agars. J Clin Microbiol 16: $1110-1116$

Williams PJleB (1975) Biological and chemical aspects of dissolved organic material in sea water. In: Riley JP, Skirrow $G$ (eds) Chemical oceanography, Vol 2, 2nd edn. Academic Press, London, p 301-363

Yentsch CS, Menzel DW (1963) A method for the determination of phytoplankton chlorophyll and phaeophytin by fluorescence. Deep-Sea Res 10:221-231

Zdanowski MK (1977) Microbial degradation of cellulose under natural conditions: a review. Pol Arch Hydrobiol 24: 215-225

Zdanowski MK (1979) Bacterial decomposition of cellulose in water polluted with paper mill waste effluents. Pol Arch Hydrobiol 26:41-63

Zdanowski MK (1995) Characteristics of bacteria in selected Antarctic marine habitats In: Rakusa-Suszczewski S, Donachie SP (eds) Microbiology of Antarctic marine environments and krill intestine, its decomposition and digestive enzymes. Department of Antarctic Biology, Polish Academy of Sciences, Warsaw, p 7-100

Zdanowski MK, Donachie SP (1993) Bacteria in the sea-ice zone between Elephant lsland and the South Orkneys during the Polish Sea-Ice Zone Expedition, (December 1988 to January 1989). Polar Biol 13:245-254

Zdanowski MK, Figueiras FG (1997) Relationships between bacterial abundance, other biota, and hydrographic variability in the Ría de Vigo, Spain. Mar Ecol Prog Ser 147: $257-267$

Zimmermann R (1977) Estimation of bacterial number and biomass by epifluorescence microscopy and scanning electron microscopy. In: Rheinheimer G (ed) Microbial ecology of brackish water environment. Springer-Verlag, Berlin, p 103-120

ZoBell CE (1941) Studies on marine bacteria. 1 The cultural requirements of heterotrophic aerobes. J Mar Res 4:42-75

Submitted: March 25, 1998; Accepted: February 1, 1999 Proofs received from author(s): May 10, 1999 